\title{
Protecting Labor Rights in Globalization: A Study on Labor Law Implement in China
}

\author{
Qiuxian Liang1, Weidong $\mathrm{Wu}^{2}$ \\ ${ }^{1}$ School of Public Management, Ji'nan University, Guangzhou, China \\ ${ }^{2}$ School of Humanities, Ji'nan University, Zhuhai, China \\ Email: 526223021@qq.com
}

How to cite this paper: Liang, Q. X., \& Wu, W. D. (2018). Protecting Labor Rights in Globalization: A Study on Labor Law Implement in China. Advances in Applied Sociology, 8, 721-733.

https://doi.org/10.4236/aasoci.2018.812043

Received: November 21, 2018

Accepted: December 25, 2018

Published: December 28, 2018

Copyright ( 92018 by authors and Scientific Research Publishing Inc. This work is licensed under the Creative Commons Attribution International License (CC BY 4.0).

http://creativecommons.org/licenses/by/4.0/

\section{(c) (i) Open Access}

\begin{abstract}
This paper employs the data from a survey conducted in Shanghai and other nine cities and uses the Logistic Regression Model to analyze it, from the perspectives of globalization. The study finds that the race to the bottom among employers may affect the behavior change of individual under laws intervention and then affect the action result of labor law's article on labor contract signing, minimum wage and basic pension plan participation.
\end{abstract}

\section{Keywords}

Law in Action, Employment Relations, Globalization, Race to the Bottom

\section{Introduction}

Developing countries face the challenge of protecting labor's rights while catching the opportunities for development in the globalization. The main challenges are: low labor income share, huge income gap between labors, poor working environment, long working hours, and lack of strong labor laws etc. Maybe this is because most of the multinational companies that are distributed in developing countries are labor cost-type. These multinational companies often use low-price labor and abundant resources in developing countries to reduce production costs and expand the consumer market, thus achieving higher profit. Under the guidance of capital, low-price labor has naturally become a mean of international competition among developing countries by deregulating labor standards so that can reduce labor costs (Olney, 2013). For example, multinational companies like Nike and Adidas have moved out from China while labor costs have generally increased. In order to prevent similar situations from happening again in China, the protection of labor rights becomes very slow. With the continuous 
declining labor standards, relatively the free flow of capital versus fixed labor, which forms a asymmetric relation, leads to labors too weaken to dialogue with capitalist (Qian, 2009). This may lower the wages and benefits of ordinary workers among many countries. And that is how the Race to the Bottom becomes (Guan, 2002). Moreover, we found that this situation exists not only between neighboring developing countries, but also in a country due to certain domestic factors (Mosley \& Uno, 2007), which aggravates the impact of race to the bottom on labor standards.

Labor law is one of the important ways to protect labors' rights, as a textual regulation that normalizes the behavior of both employers and employees. It helps protect the rights of workers in developing countries in the era of globalization and avoids the deeper harm under the race to the bottom. Labor law can not only regulate the obligation of negotiation between employers and employees, but also define the boundaries of negotiation between the two parties. The contract can be used to deal with disputes through legal way instead of the strength of them, which means that the law can solve the conflict more effectively than the labor regulations and promote social equity (Shulman \& Harry, 1955). However, in the process of implementation, labor laws will also encounter pressure and obstruction from companies. As a developing country with a large population, China is facing more complicated problems in the economic globalization. The Labor Law of the People's Republic of China (the "Labor Law"), which was implemented in 1995, and the Labor Contract Law of the People's Republic of China (the "Labor Contract Law") implemented in 2008 have further improved the legal system of the Chinese labor market. However, the dilemmas encountered during the implementation process show the complexity of labor relations and the difficulty of legal action under economic globalization. China is a big country in economic globalization, and there are obvious differences in labor standards between local governments. In this study, we take the textual provisions on labor contract signing, minimum wage standards and basic endowment insurance participation in Chinese labor law by analyzing Shanghai and other ten cities data. We explore the impact of race to the bottom about the protection of Chinese labor rights under globalization from the action effect level of labor law.

\section{Model and Variable Settings}

The basic research question of this study is: Will the competition based on economic globalization between labors and employers affect the action result of labor law texts? Among them, the concept of "action result of labor law texts" refers that the text of the law stipulates in practice, it exerts influence on the subject of the labor relationship which make the behavior of the subject change under the influence of the law. The results of changing mainly include two types: 1) the text of the labor law is executed and the behavioral norms stipulated in the legal provisions evolving into the actual behavior of the subject of the act; 2) the 
text of the labor law does not obtain. The agent rejects to conduct the legal provisions. Being obeyed" and "not being observed" is a dichotomous variable. We can use the binary logistic regression model to test and analyze the relevant influencing factors.

\section{1) Dependent variable}

China's labor laws contain a very rich textual content. On the basis of the Constitution, the Labor Law was promulgated in 1994 and became the first labor law after the founding of New China. Since then, the legislature has successively promulgated the Safety and Health Law, the Labor Contract Law, The Dispute Mediation and Arbitration Act and the Social Insurance Act, as well as a considerable number of administrative and departmental regulations (Zheng, 2014). In this empirical study, it is difficult to achieve all-round, to discuss all the provisions of labor law texts, but only to choose and focus some key areas of significant impact as the goal. In this study, the texts of three labor laws, such as Labor Contract Signing, Minimum Wage Regulations" and "Basic Endowment Insurance, were selected to conduct empirical research.

a) Signing a labor contract

The labor contract is the primary and basic content of the legal regulation in free labor market (Chang, 2013). The reality of labor relations, especially the low labor contract signing rate, short term and irregular content in the implementation of the labor contract system, is the realistic basis for the formulation of the Labor Contract Law (Chang, 2008). Promoting the signing rate of labor contracts is one of the key tasks of China. According to the statement of the Report of the State Council on the Work of Protecting the Labor's Legal Rights, "labor contracts are important carriers for implementing labor security laws and regulating the rights of both parties in labor relations." In 2005, the "Report of the Law Enforcement Inspection Group of the National People's Congress on the Labor Law of the People's Republic of China" pointed out that there are still many problems in implementing the "Labor Law", and some problems are still serious. The mainly problem are that the labor contract signing rate is low, the term is short, and the content is not standardized. The signing rate of labor contracts for small and medium-sized non-state-owned enterprises is less than $20 \%$, and the rate of signing individual economic organizations is lower. Since 2011, the labor contract signing rate has become one of the necessary contents in the annual statistical report on the development of human resources and social security. At the same time, according to the 2008 statistical report, the national labor security supervision institution and ordered the employers to re-sign the labor contract up to 15.617 million workers, after passing the labor security supervision. By 2015, the number of labor re-signed contracts was still as high as 3.071 million. From these data, it is still a considerable problem of employers refusing to sign labor contracts. At this stage, it is still one of the key issues in China's labor law. This study is based on the text of the labor contract. To establish a labor relationship, a labor contract should be concluded, which is an important clause 
of the Labor Contract Law and the result in practice is the signing of a labor contract. If employer and the employee sign a labor contract, then the labor law can be considered that the textual content of the labor contract has been obeyed. However, if the employer and the employee do not sign a labor contract, it is considered that this text of the labor law has not been observed.

b) Minimum wage regulations

The Labor Law promulgated in 1994, in Article 48, stipulates that "the state implements a minimum wage security system. In the same year, the Ministry of Labor issued the Notice, marking the initial establishment of the minimum wage standard. In 2004, the Ministry of Labor and Social Security promulgated the "Minimum Wage Regulations", which detailed the scope, form, composition, remedies for violation of the minimum wage, and dispute resolution of the minimum wage. It is more workable contrasting to the 1994 Minimum Wage Regulation (Shen, 2009). After a period of practice, the National People's Congress on the Inspection of the Implementation of the Labor Law pointed out that the minimum wage system has not been fully implemented, and the phenomenon of wage arrears still occurs from time to time. The Labor Contract Law of 2008 made a new and compulsory agreement on labor relations in labor remuneration, minimum wages, which reduced the space for enterprises to swing the minimum wage, and make the required enforcement force (Ding, 2010):

In the legal text, the "Labor Contract Law" stipulates in Article 20 that "the wages of labors during the probation period shall not be less than $80 \%$ of the minimum wages of the same post or the wages agreed in the labor contract, and shall not be lower the minimum wage standard at the location of the employer." In Article 72, "the hourly wage standard for non-full-time employment shall not be lower than the minimum hourly wage standard prescribed by the peoples government where the employer is located". After the labor relationship is established between the labor and the employer, including during the probationary period, the wages of the laborer cannot be lower than the local minimum wage. The empirical data used in this research is derived from the "Labor Employment Status Questionnaire" conducted in 2010 in Shanghai, Shenzhen, Tianjin, Mianyang and Changchun etc. In the quantitative model, it is compared whether the workers' monthly income can exceed the monthly minimum wage in 2010. If it can be exceeded, the text content of the minimum wage requirement will be observed. If not exceeded, the text of the minimum wage rule is considered not to be complied. It must be pointed out that the issue of labor income in the "Labor Employment Status Questionnaire" is the total income including wages, subsidies, and overtime pay but not including overtime and allowances. Therefore, the discussion of violations of the minimum wage regulations in this study is more serious.

c) Basic pension insurance participation

China's pension insurance system, the "Labor Insurance Regulations of the People's Republic of China" promulgated and implemented in 1951 as its official 
establishment. When the regulations were promulgated, they only covered employees in some urban enterprises. The Labor Law of 1994 contains Chapter 9 on social insurance and welfare which means China's pension insurance system entering a legal era. In 1997, the "Decision of the State Council on Establishing a Unified Basic Endowment Insurance System for Enterprise Employees" unified the national institutional arrangements. Subsequent series of regulations and policies standardized the collection and management of pension insurance, financial management, labor insurance supervision, fund investment, and further improved the operational capacity of the system. In the Labor Contract Law of 2008, Article 17 stipulates that labor contracts should have a series of clauses. One obvious change compared with the Labor Law is that they include social insurance.

Article 10 of the Social Insurance Law stipulates that employees should participate in basic endowment insurance, and the basic endowment insurance premium should be share between employer and employees. As the primary item in China's social insurance system, the payment of basic endowment insurance for employees is often the highest part in social insurance programs, and the pressure on capital expenditure for employers is higher than other insurance types. We should avoid participation in basic endowment insurance becoming an option for some employers to low labor costs and obtain more profits. According to the statistics of China Statistical Yearbook 2010 and China Labor Statistics Yearbook 2010, although the proportion of unemployed people who have not paid pension insurance has gradually declined since 1990, the number of people who did not participate in pension insurance at the end of 2009 is still high. 9550. 80,000 people, accounting for 34.5\% (Tian, 2014) of urban employees other than administrative and institutional personnel. A considerable number of workers do not have participated in the basic pension insurance system because of the implementation of labor laws. Therefore, this study explores the participation of basic pension insurance.

\section{2) Independent variable}

Many scholars are involved in race to the top while discussing race to the bottom, which is also an important analytical framework for understanding the relationship between employers and workers in the globalization. Under the race to the bottom and the motivation of pursuing the maximum profit, the employer used investment as a bargaining means to low local labor standards. Under the dual pressure from employers and policies, workers are in a disadvantaged position and have weak ability to negotiate with employers. But in fact, not every industry will lower the labor standards to a minimum, some will be higher than the general standards, and even to the top. It can be seen that race to the bottom is partly a game between the employer and the labor about resources. The strength of the game depends on the scarcity of the resources it owns and the dependence on the other's resources. The result is the separation of labor negotiation power, the dominant side and the weak side. For example, the British 
Brexit, local laborers expel foreign workers, with the hope to obtain the dominant position in the negotiation game, to reduce the damage caused by the race to the bottom. In fact, the laws on labor relations most likely are affected by the race to the bottom. If resource and power are balance between the two sides, the textual provisions of labor laws should be better executed by both employers and employees. However, if the resources of the two parties are not balanced and one subject has greater game power, then the agent has at least two possible behavior choices: a) refusing to conduct the behavior, using its own additional power, or forcing the other party in the labor relationship to make a specific compromise, thereby circumventing the legal constraints; b) complying with the law, conducting power concessions and behavioral changes. Theoretically, the race to the bottom will affect the behavioral choice even under the labor law intervention, thus affecting the action results of the labor legal text. In the choice of variables, this study mainly focuses on industry categories, household registration, education level and professional and technical qualifications.

First, the industry is closely linked to the supply and demand of the labor market. Under the economic globalization, the proportion of labor-intensive industries is relatively large. Under the resource-regulating mechanism of the market economy, enterprises in a certain industry may face sufficient labor supply at a certain period, and have abundant alternative labor resources, thus reducing the enterprise's labor resource dependence. The company's has advantage and the negotiation ability is strong. In contrast, enterprises in some industries may lack of the alternative labor resources due to the shortage of labor supply, thereby increasing the dependence on labor resources, and the game ability of enterprises decline. In the macro labor market, the labor supply and demand situation of the industry is a relatively clear reflection of the relative advantage of the resource game between the labor and the employer.

Secondly, in terms of the household registration system, migrant workers (farmers) from rural areas have a higher degree of dependence on the economic resources (salary wages) provided by employers than urban workers. On the one hand, the main reason for rural migrant workers to work in cities is to obtain more income than farming at home. On the other hand, a person who has migrated have more expenses in housing than urban workers, but they are not eligible to receive relief from the minimum living security system for poor people in urban areas. In the absence of wage income, it is difficult for rural labors to stay in urban for a long time. Based on the desire of the employer for low labor costs of economic globalization, rural workers may be in a relatively inferior position when negotiating with the employers, which affecting the rural labors' rights.

Finally, the scarcity of labor resources determines the level of substitutability, which affects the power game pattern between employers and employees. The higher the scarcity of labor resources provided by laborers, the higher the degree of dependence of employers on workers, and the greater power of labors. In this case, it can enable employer to follow the textual norms of the law. The lack of 
resources that labors can provide depends on the degree they have. School education is the main way for laborers to learn skills, enhancing working value in modern society. At the same time, the professional and technical qualification system is the basic evaluation system for Chinese professional and technical personnel. The professional and technical qualifications reflect the work ability and work achievement of the workers (Wu, 2014). The acquisition of professional and technical qualifications often also means that laborers have relatively scarce labor resources.

\section{3) Control variables}

In terms of control variables, this study included basic demographic social variables (sex and age of workers), occupational variables (worker's time of service, job category, and monthly income), as well as variables in the employer's sector (corporate ownership and Scale) to more accurately explore the relationship between resource dependence and the outcome of actions in labor law texts.

\section{Data}

The data used in this study is derived from the Labor Employment Survey. Based on the availability and effectiveness of the data, we select these ten cities. The survey began in September, 2010 and was launched in ten cities including Shanghai, Shenzhen, Tianjin, Nanjing, Changsha, Chengdu, Wenzhou, Xiamen, Mianyang and Changchun. In the research, this questionnaire mainly uses the multi-stage sampling method, according to the order of "district-street-community-worker". The sample of the district is first taken from the administrative district of the surveyed city, and then Samples of the streets were taken from the streets of the district samples, community samples were taken from the community of the street samples, and surveys were conducted in the community by investigators. At the same time, screening questions were set in the questionnaire. Only after confirm the identity of the respondents, which means officially workers not a student or other groups, then the follow-up questionnaires were continuously conducted. We distributed 2000 questionnaires in the survey, and 1800 valid questionnaires were obtained. The effective recovery rate of the questionnaire was about $90.0 \%$. The geographical distribution is as follows: 293 in Shanghai, 195 in Nanjing, 300 in Shenzhen, 190 in Tianjin, 197 in Changsha, 208 in Chengdu, 105 in Wenzhou, 100 in Xiamen, 104 in Mianyang and 108 in Changchun. The basic situation of the survey sample is shown in Table 1 .

\section{Findings}

In order to test the impact of global competition on the execution results of labor law on labor contract signing, minimum wage standards and basic pension insurance participation, this study set a logistic regression model. The results of the regression analysis are shown in Table 2. 
Table 1. Basic information of the survey sample.

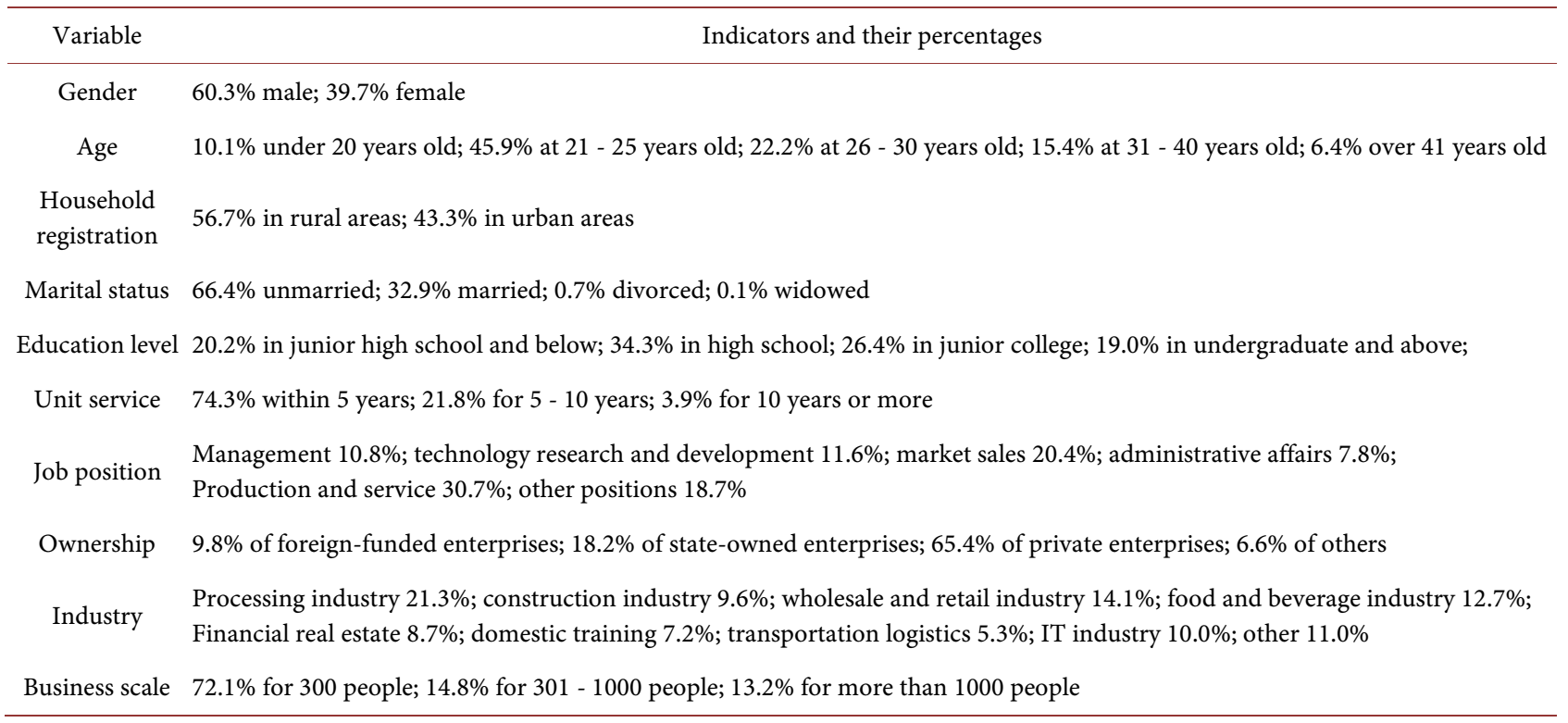

From the regression results, it can be clearly found that the industry has significant effects on the three dependent variables such as labor contract signing, minimum wage regulations and basic endowment insurance participation. In terms of labor contract signing, the rate of labor contract signing in other industries is not as good as that in manufacturing. Among them, the construction industry only has $40.0 \%$ of the manufacturing industry, $40.5 \%$ of the business, and the service industry is $42.8 \%$, all of which are less than half, and concentrated in $40 \%$ or so. As a result of this data, it is more obvious that the manufacturing industry and the industry group consisting of construction, commerce and service industries are two categories. The signing of labor contracts in the manufacturing industry is clearly better than this industry group, forming a special category. Similarly, there is a similar result in the participation of basic pension insurance: the participation of the construction industry and the service industry is only about half of the manufacturing industry. Finally, in terms of minimum wage regulations, the service industry with significant regression results, the monthly income of workers can be higher than the local minimum wage standard, which is only $45.2 \%$ of the manufacturing industry. It can be found that the manufacturing industry's labor law texts on labor contract signing, minimum wage regulations and basic pension insurance participation are obviously superior to other industries. While economic globalization has brought a lot of employment opportunities to China, it is mainly concentrated in the manufacturing industry. At this stage, the distribution of low-cost labor in China has changed. The shortage of general workers and technicians in the manufacturing industry has been going on for some years in some coastal areas and is currently spreading to inland areas. In order to hire enough laborers to maintain the production and operation of the company, manufacturing companies have increased the remuneration of workers. The signing of labor contracts, higher labor compensation, 
Table 2. Action results of resource dependence and labor law texts: Logistic regression model.

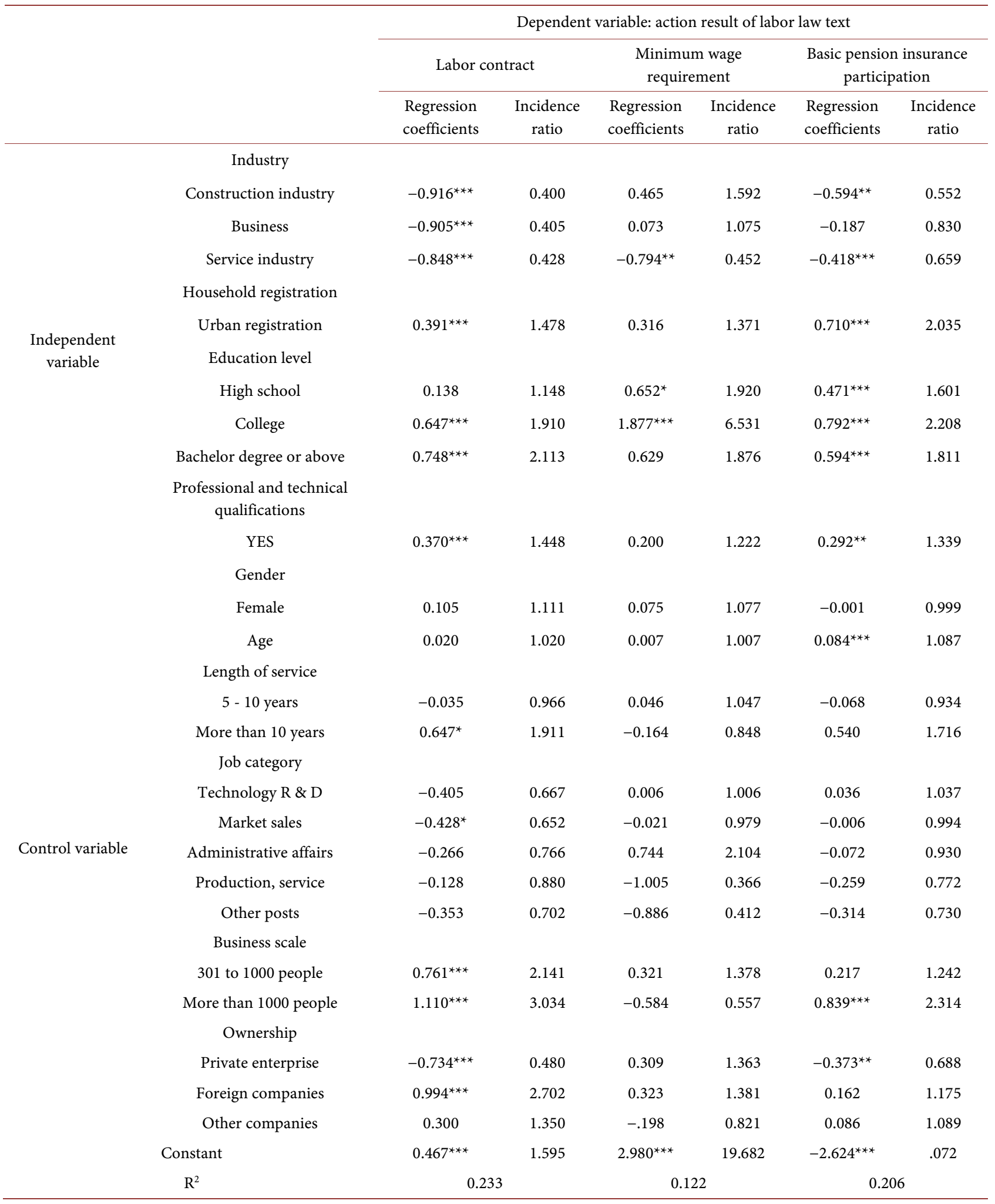

Note: (1) The industry is based on the processing industry. The household registration status is based on rural household registration. The education level is based on junior high school and below. The professional and technical qualifications are not based on reference. The gender is based on men and the working age is less than 5 years. For reference, the post category is based on the management category. The scale of the company is based on 300 or less. The ownership is based on state-owned enterprises. (2)* indicates $\operatorname{sig}<0.1$, ${ }^{* *}$ indicates $\operatorname{sig}<0.05$, and ${ }^{* * *}$ indicates $\operatorname{sig}<0.01$. 
and basic social insurance have become the main ways for many manufacturing companies to attract workers and stabilize production teams. At the same time, due to the existence of institutional constraints, China's "labor shortage" and the coexistence of rural surplus labor are still likely to continue at this stage and for some time to come (John et al., 2011). The shortage of labor is mainly in the manufacturing industry, while other industries are still facing a relatively abundant labor market. The bottoming out of economic globalization is mainly manifested in labor-intensive industries, while labor shortages occur in the manufacturing industry. In the process of negotiating with the employers, the workers have significantly improved their status, which has reduced the level of labor standards to a certain extent, thus leading to different Labor law action results. The higher the demand for labor resources in the industry in which the employer is located, the lower the competition for the labor standards between the employers, the employment contract between the employer and the laborer, the provision of wages that meet the minimum wage, and the possibility of basic pension insurance. The higher the sex, the more relevant textual provisions of the labor law can be more effectively enforced by the actors.

In terms of household registration, the proportion of workers in urban household registration in labor contract signing and basic endowment insurance participation is significantly higher than that in rural household registration, which is 1.478 times and 2.035 times respectively. Although the regression coefficient in terms of the minimum wage is not significant, the relationship is positive. The higher dependence of rural household workers on employers on economic resources and the strong attraction of low labor costs to capital under the guidance of economic globalization are likely to make rural household workers in a more vulnerable position in labor relations. The situation of bottoming competition is more obvious. When employers face rural laborers, they are more likely to fail to comply with current labor laws in terms of labor contract signing and basic endowment insurance participation.

Finally, the incidence ratio of labor contract signing, minimum wage regulations and basic endowment insurance participation is basically improved with the improvement of the education level of workers. The incidence of labor contracts signed by junior college graduates is $91 \%$ higher than that of junior high school and below, and the undergraduate degree or above is further increased to $111.3 \%$. A similar situation exists in the participation of minimum wage regulations and basic pension insurance. The general rule is that the higher the education level of the workers, the three labor law texts focused on this study can also achieve better implementation results. In addition, although there is no significant impact on the minimum wage requirement, professional and technical qualifications also contribute to the signing of labor contracts and the participation of basic endowment insurance. For workers with professional and technical qualifications, the ratio of labor contracts is 1.448 times that of workers who lack relevant qualifications, and the possibility of participation in basic pension insur- 
ance is the number of workers who lack relevant qualifications. 1.339 times. The regression results of these two variables show that higher education levels and the acquisition of professional and technical qualifications contribute to the realization of labor law texts. Under the globalization of economy, multinational corporations need to recruit talent development markets that are familiar with their national conditions and enter the market. Under the demand of talent quality, there may be "topping competition" of talents rather than bottoming competition. Higher education and the acquisition of professional and technical qualifications often mean that laborers have higher levels of labor resources, and the irreplaceability of resources is higher. Employers are more dependent on them than those with lower education. The power structure is more balanced, which may result in more compromises on the legalization of labor relations, and then sign labor contracts between the two parties, providing workers with wages higher than the minimum wage and opportunities to participate in basic pension insurance.

\section{Conclusion}

The above analysis shows that the industry, household registration, and education level have a significant impact on labor law on the signing of labor contracts, minimum wage regulations, and basic pension insurance. Whether or not the labor standards compete for bottoming depends on the scarcity and dependence of labor resources. The result of the performance is that the manufacturing industry is in compliance with labor laws due to labor shortage; the rural household labor relies on economic resources, employing people. The unit forces the laborers to compromise, and then circumvents the constraints of labor laws; the laborers have a high degree of education and a small number, and the employers abide by the labor laws.

The introduction of a law usually pays attention to the consistency of legal texts and law enforcement, that is, whether the law enforcement is not biased by the legal text. However, in reality, China's "Labor Law" and "Labor Contract Law" have a "sub-standard" phenomenon in the process of implementation. In other words, under the mandatory standards of labor law, the implementation of labor law has produced a set of the common standards (Zheng \& Sun, 2011) that the government, laborers, and other related parties default to and comply with. The deviation between the provisions of the Labor Law and the actions has led to significant impacts on the signing of labor contracts, the minimum wage standards and the signing of basic pension insurance in different industries, different household registrations and different educational levels. The above situation is traceable. Since 2008, China has implemented the Labor Contract Law. In 2009, the financial turmoil, corporate bankruptcy collapsed, and there were a large number of labor dispute cases in China. Local governments have adjusted the standard of the Labor Contract Law, exerting local initiative, lowering labor protection standards, and triggering "bottoming competition" between local and 
local governments (Zhou, 2010). The "Labor Contract Law" is "untimely" and has a significant impact on its legal action effects, resulting in a lack of cooperation between local governments, falling into a "prisoner's dilemma", forming bottom-up competition, reducing labor welfare expenditures, and undermining the interests and labor of employers balance of interests (Revesz, 1992).

In the globalization, in order to attract foreign investment, developing countries hand over labor to the market by relaxing labor control. Under the pressure of the employer, the workers in developing countries compromised the reality. On the one hand, the government must retain capital, on the other hand, it must introduce policies to provide minimum protection for workers, and the limit of labor protection is the result of "bottoming competition", but even if there are relevant labor laws, the situation of legal action derailment happens. China faces a situation similar to that of most developing countries. It attracts capital and faces the challenge of protecting labor rights. China's labor laws will inevitably be affected by bottoming competition.

\section{Fund}

National Social Science Fund Project "Social Policy Research on Transforming Economic Development Mode in China at Present Stage" (Project No.: 11ASH009).

\section{Conflicts of Interest}

The authors declare no conflicts of interest regarding the publication of this paper.

\section{References}

Chang, K. (2008). On the Legislative Basis and Legal Position of Labor Contract Law. Law Forum, 23, 5-14.

Chang, K. (2013). Collectivization of Labor Relations and Improvement of Government Labor Policies. Social Sciences in China, 35, 82-99.

Ding, S. H. (2010). Analysis of Employment Effect of Minimum Wage Control-Also on the Interaction Effect of "Labor Contract Law". China Social Sciences, No. 1, 85-102.

Guan, X. P. (2002). Economic Globalization, Social Inequality and China's Social Policy Transformation-Also on the New Challenges after Entering WTO. Southeast Academic, No. 6, 43-49.

John, K., Deng, Q. H., \& Li, S. (2011). China's Labor Shortage and Rural Surplus Labor Force. Management World, No. 11, 12-27.

Mosley, L., \& Uno, S. (2007). Racing to the Bottom or Climbing to the Top? Economic Globalization and Collective Labor Rights. Comparative Political Studies, 40, 923-948. https://doi.org/10.1177/0010414006293442

Olney, W. W. (2013). A Race to the Bottom? Employment Protection and Foreign Direct Investment. Journal of International Economics, 91, 191-203. https://doi.org/10.1016/j.jinteco.2013.08.003

Qian, J. X. (2009). The Evolution of Labor-Management Relationship in Developed Countries in the Age of Globalization and Its New Trends. Socialism Research, No. 6, $113-116$

Revesz, R. L. (1992). Rehabilitating Interstate Competition: Rethinking the 
Race-to-the-Bottom Rationale for Federal Environmental Regulation. New York University Law Review, 67, 1210.

Shen, T. E. (2009). Research on the Legislative Model of China's Minimum Wage Labor Standards. Administration and Law, No. 12, 113-116.

Shulman, H. (1955). Reason, Contract, and Law in Labor Relations. Harvard Law Review, 68, 999-1024. https://doi.org/10.2307/1337783

Tian, J. G. (2014). On the Harm, Causes and Governance of China's Endowment Insurance Escape Fees. Social Security Research, No. 1, 33-45.

Wu, F. (2014). Summary and Prospect of Research on Professional Technology Qualification System in China. Academic Forum, 37, 41-45.

Zheng, G. H., \& Sun, Z. W. (2011). The "Second Standard" in the Execution of Labor Law-Based on the Investigation of Peasant Workers in the Pearl River Delta from 2006 to 2010. Social Sciences, No. 12, 90-100.

Zheng, S. Y. (2014). Twenty Years of Labor Law, Ten Years of Academics-Commemorating the 20th Anniversary of the Labor Law and the Prospect of Labor Law Research. Tsinghua Law, No. 4.

Zhou, C. Z. (2010). Implementation of Labor Contract Law under the Background of International Financial Crisis-Concurrently on the Role and Limitation of Judicial Activism in Labor Dispute Resolution. Tsinghua Law, No. 5, 16-24. 